Supporting Information

\title{
Spin-Coated Thin Films of Polycyclic Aromatic Hydrocarbons Exhibiting High SCLC Hole Mobilities
}

Yong Li, Robert G. Clevenger, Lu Jin, Kathleen V. Kilway, * and Zhonghua Peng*

Department of Chemistry, University of Missouri-Kansas City, Kansas City, Missouri, 64110, United States

pengz@umkc.edu; kilwayk@umkc.edu 


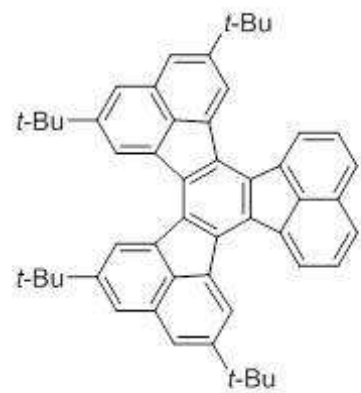

1
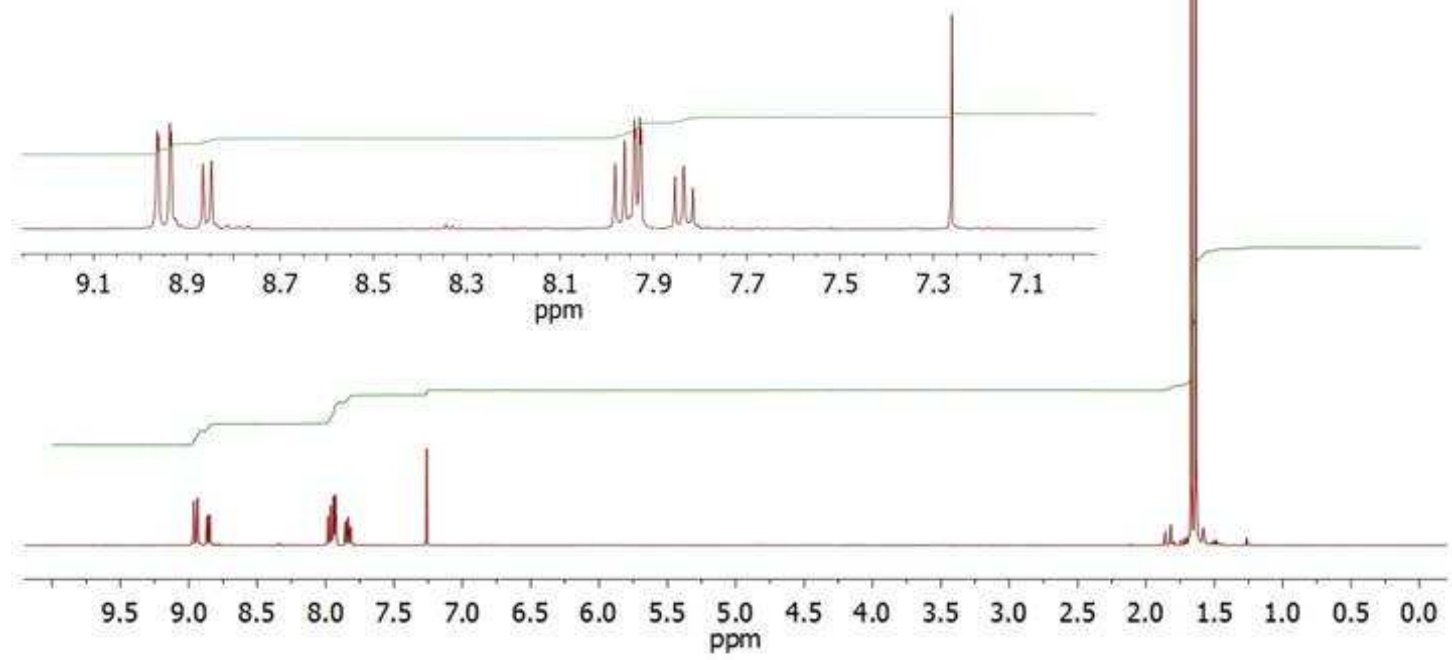

Figure S1. ${ }^{1} \mathrm{H}$ NMR spectrum $\left(400 \mathrm{MHz}, \mathrm{CDCl}_{3}\right)$ of compound 1. 

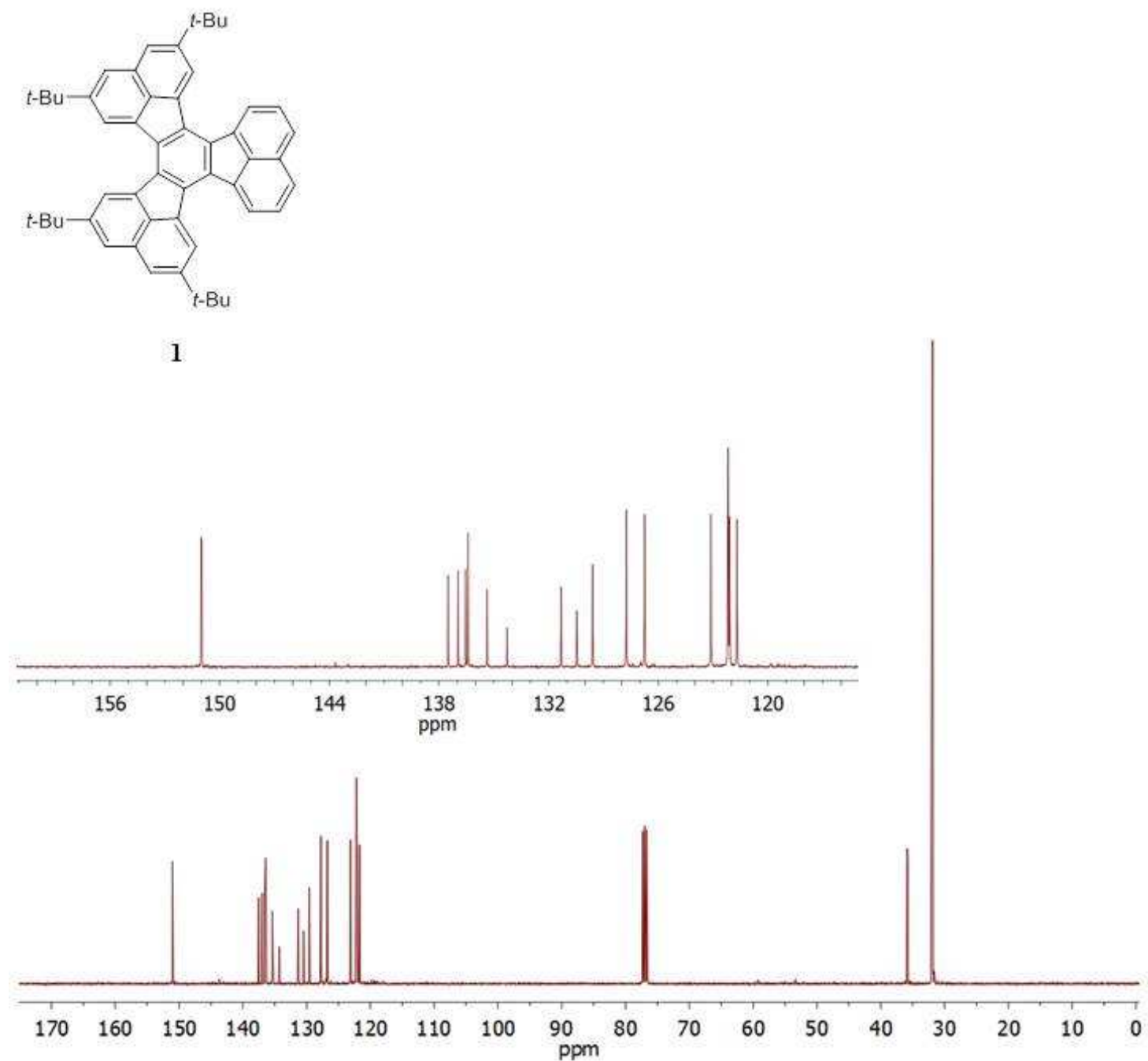

Figure S2. ${ }^{13} \mathrm{C}$ NMR spectrum $\left(100 \mathrm{MHz}, \mathrm{CDCl}_{3}\right)$ of compound $\mathbf{1}$. 


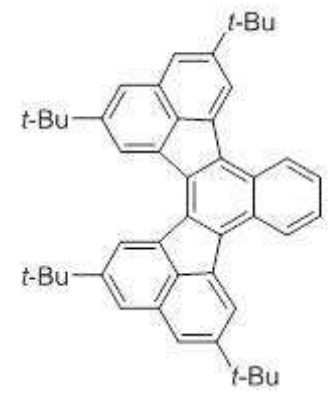

3

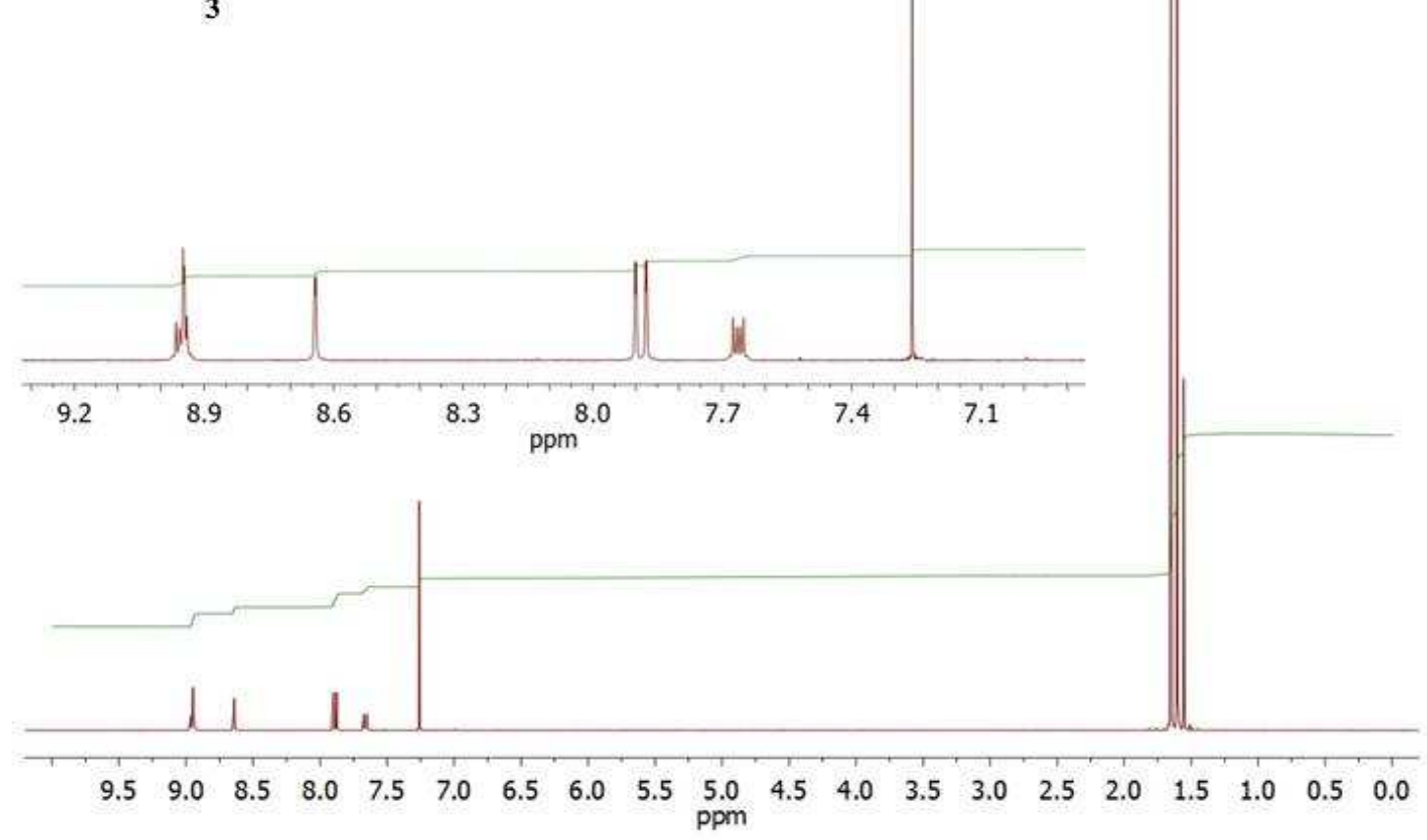

Figure S3. ${ }^{1} \mathrm{H}$ NMR spectrum $\left(400 \mathrm{MHz}, \mathrm{CDCl}_{3}\right)$ of compound 3 . 

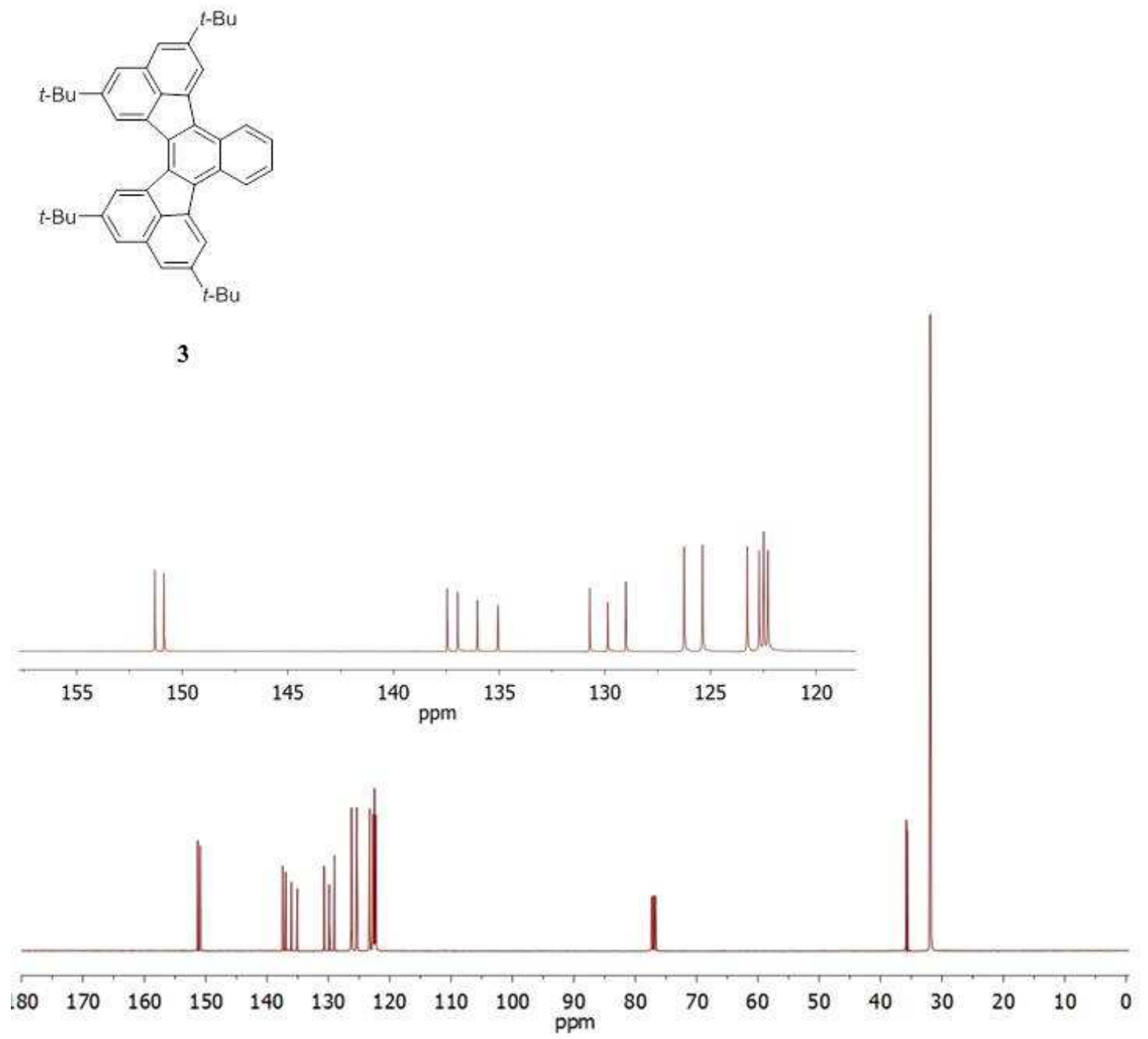

Figure S4. ${ }^{13} \mathrm{C}$ NMR spectrum $\left(100 \mathrm{MHz}, \mathrm{CDCl}_{3}\right)$ of compound 3 . 

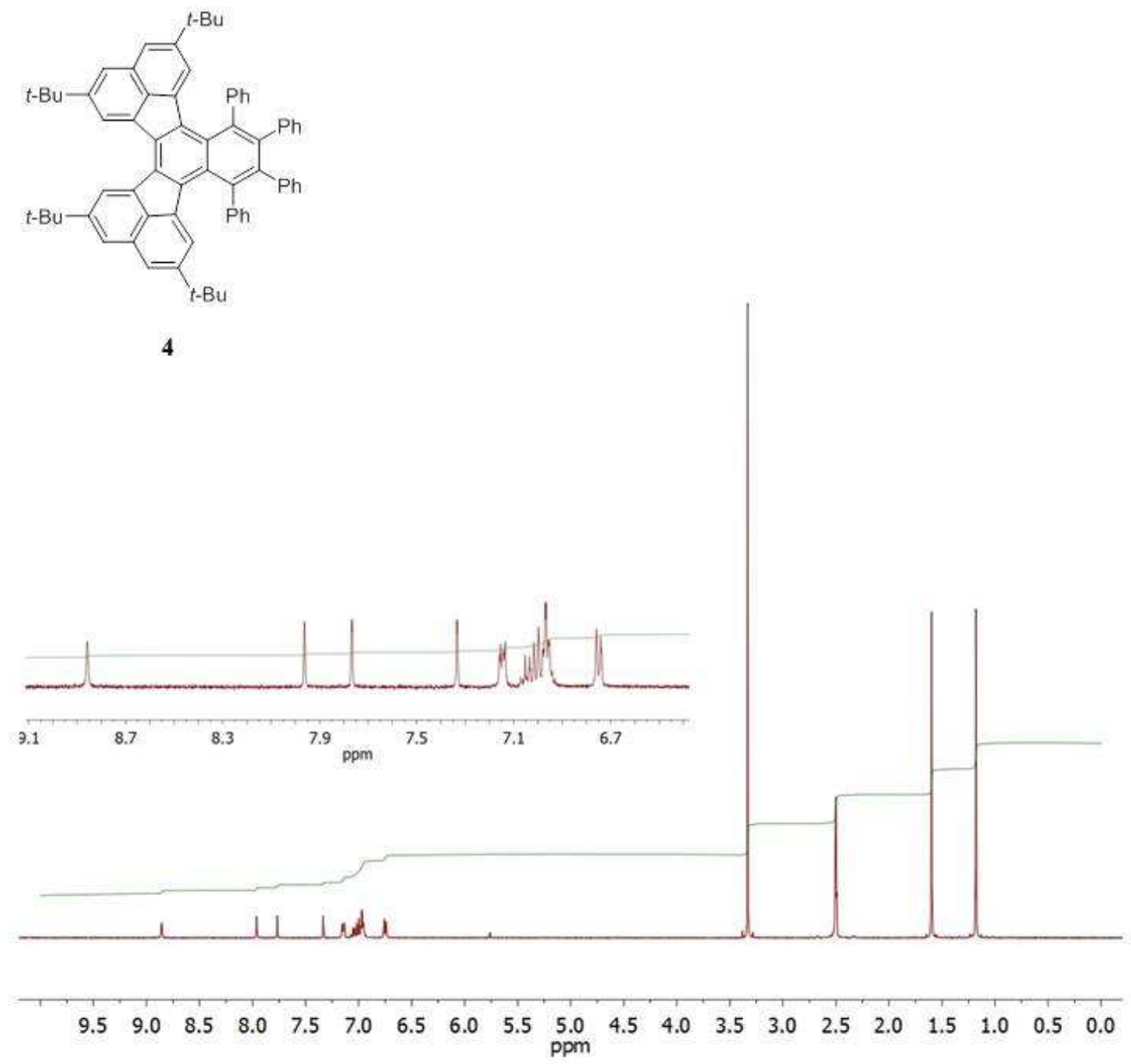

Figure S5. ${ }^{1} \mathrm{H}$ NMR spectrum ( $400 \mathrm{MHz}$, DMSO- $d_{6}$ ) of compound 4. 


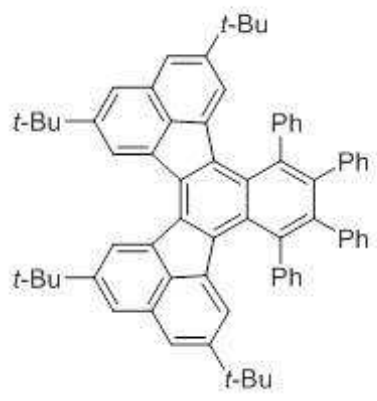

4
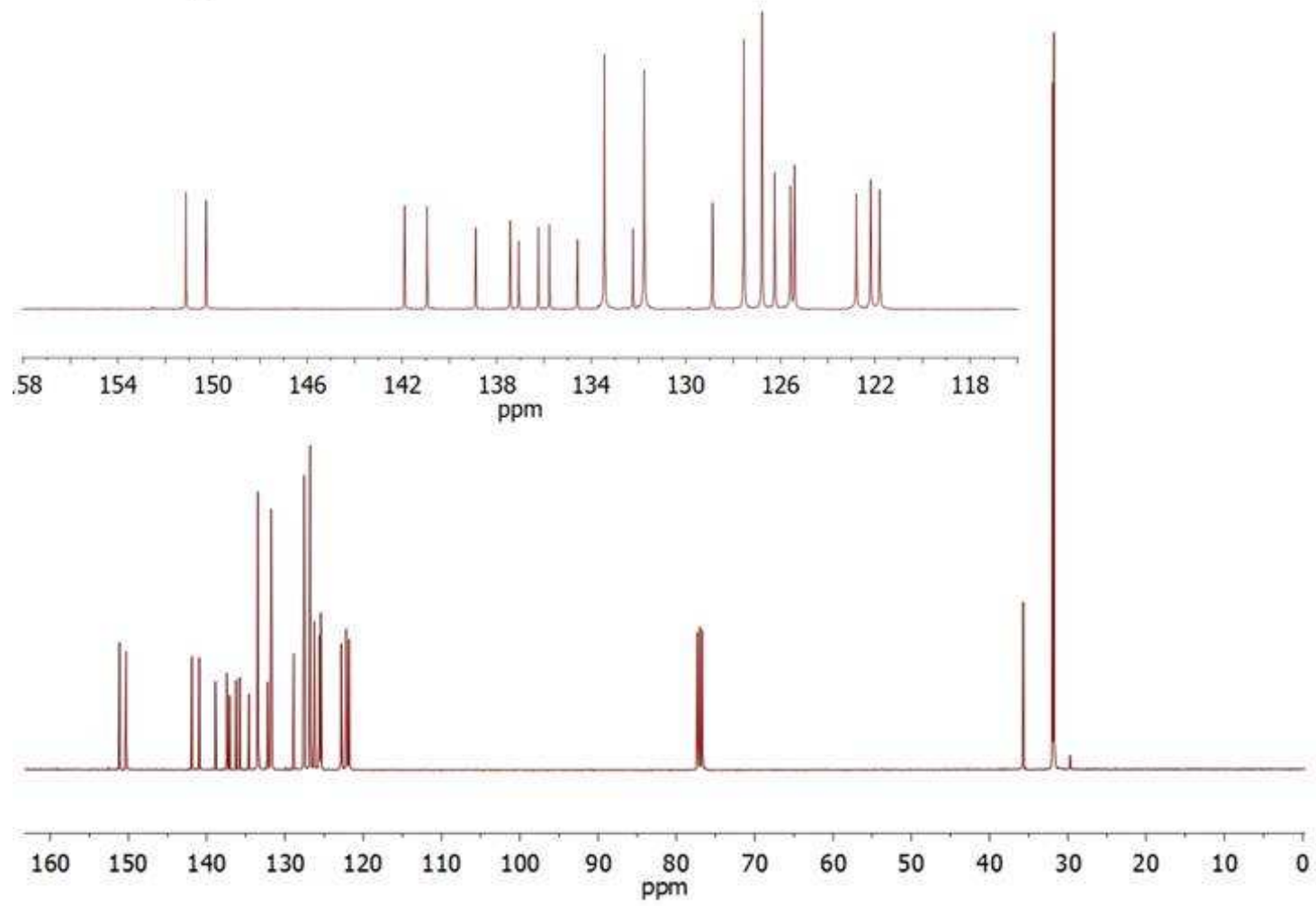

Figure S6. ${ }^{13} \mathrm{C}$ NMR spectrum ( $400 \mathrm{MHz}, \mathrm{CDCl}_{3}$ ) of compound 4 . 


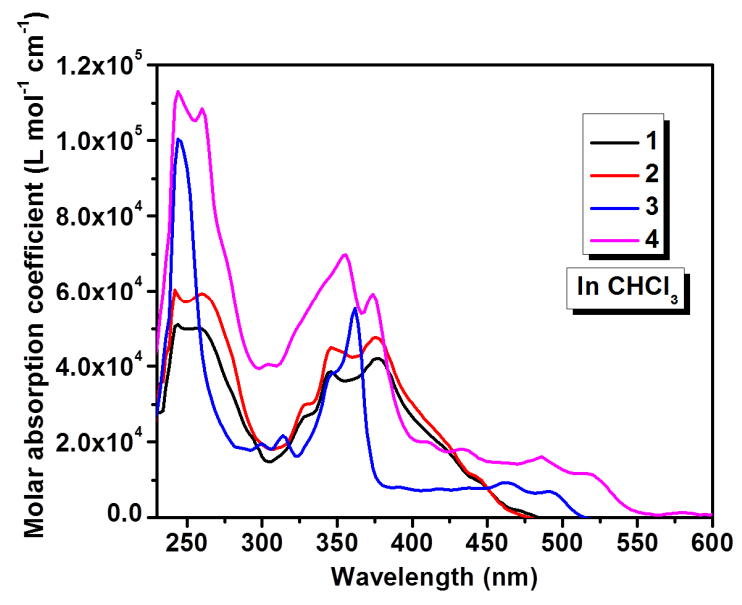

Figure S7. Molar absorptivity spectra of compounds 1-4 in $\mathrm{CHCl}_{3}$.

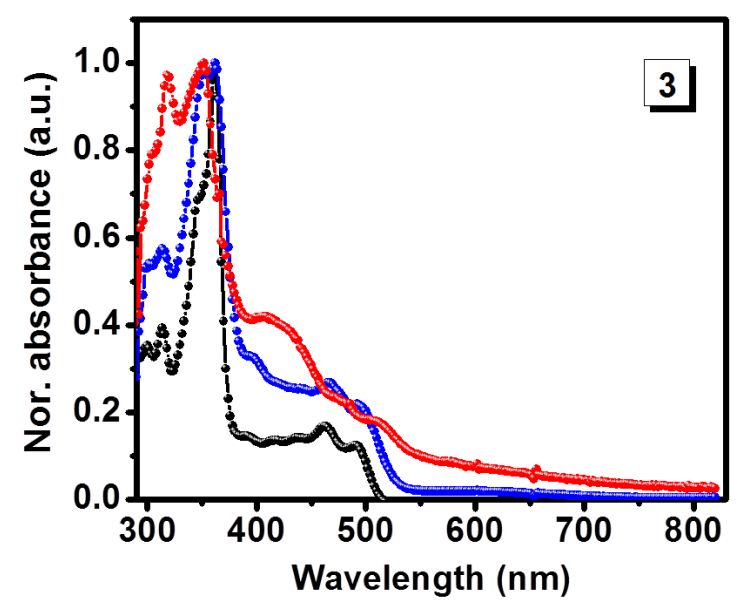

Figure S8. Normalized UV-visible absorption spectra of compound $\mathbf{3}$ in $\mathrm{CHCl}_{3}$ (black) and as thin films (unannealed: blue; annealed: red). 

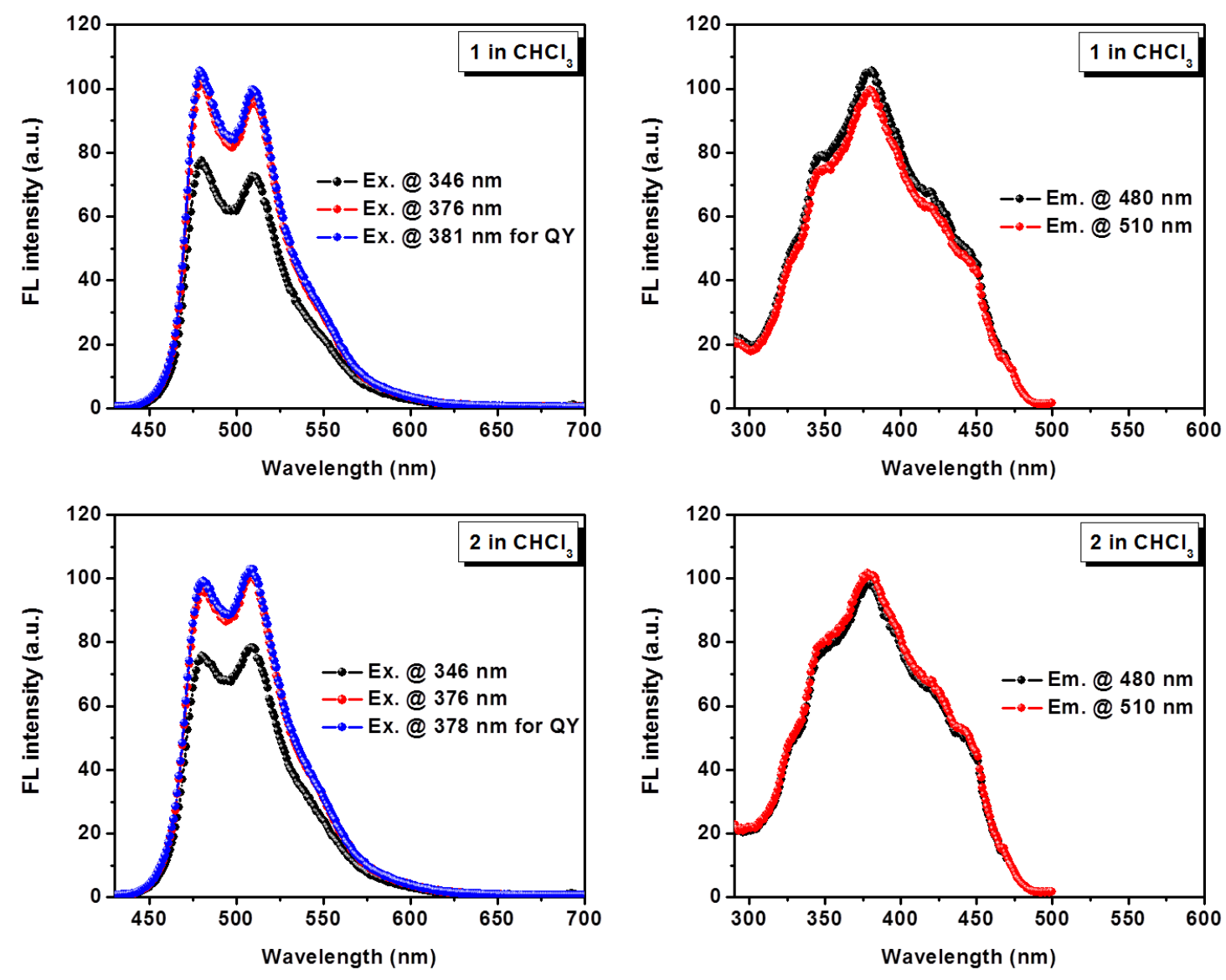

Figure S9. Fluorescence emission and excitation spectra of compounds $\mathbf{1}$ and $\mathbf{2}$ in dilute $\mathrm{CHCl}_{3}$ solutions monitored at different wavelengths. 

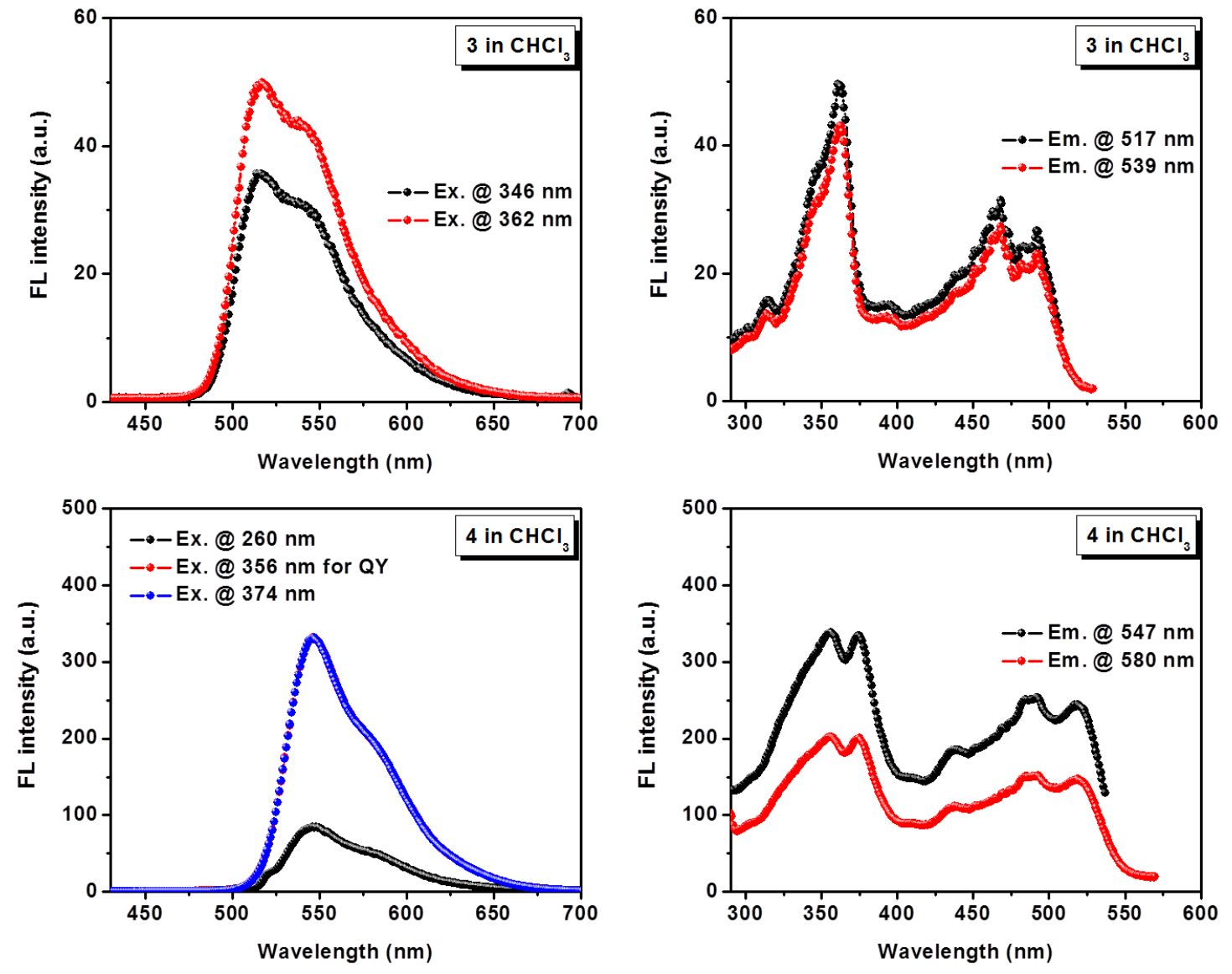

Figure S10. Fluorescence emission and excitation spectra of compounds 3 and 4 in dilute $\mathrm{CHCl}_{3}$ solutions monitored at different wavelengths. 

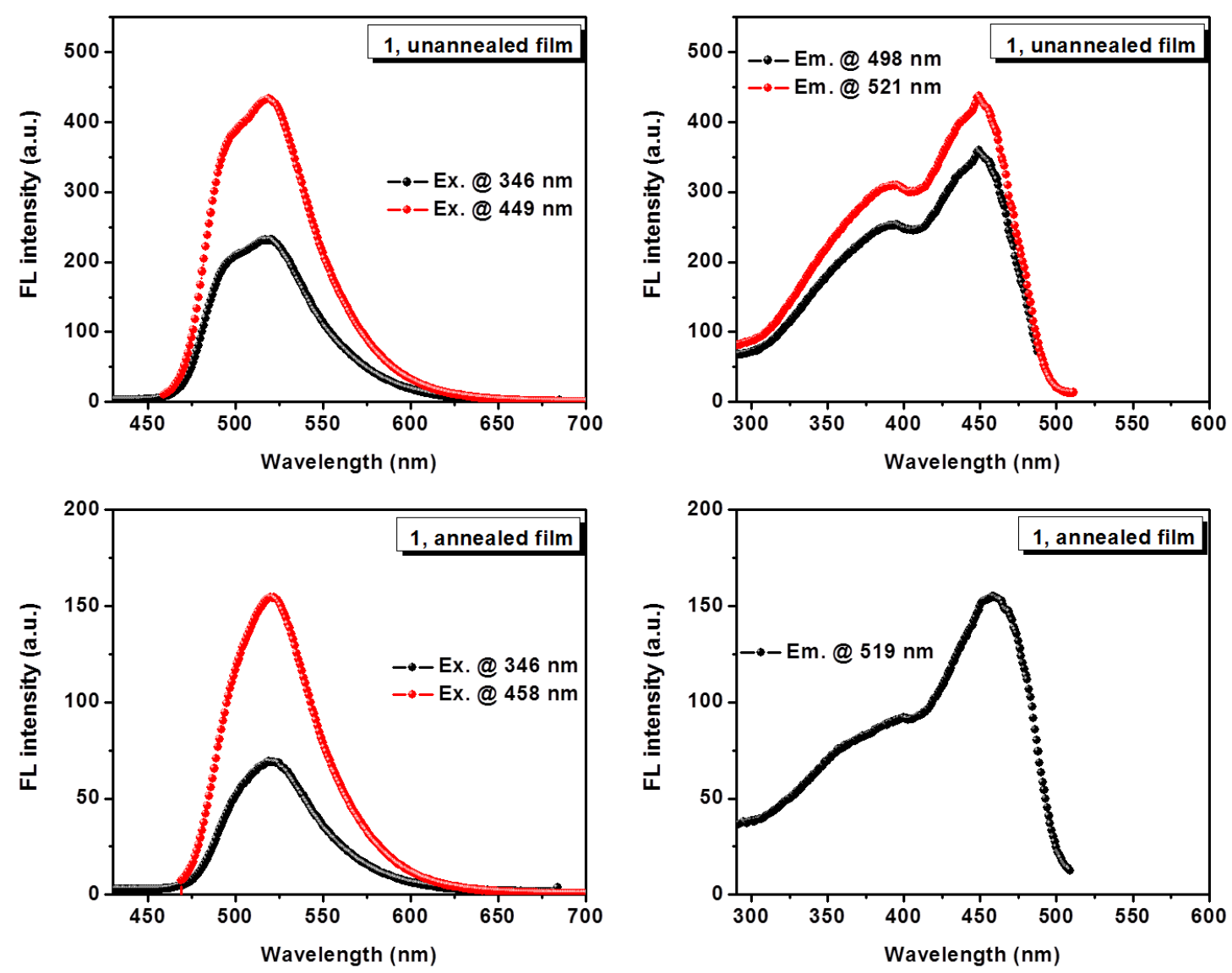

Figure S11. Fluorescence emission and excitation spectra of unannealed and annealed thin films of compound 1 monitored at different wavelengths. 

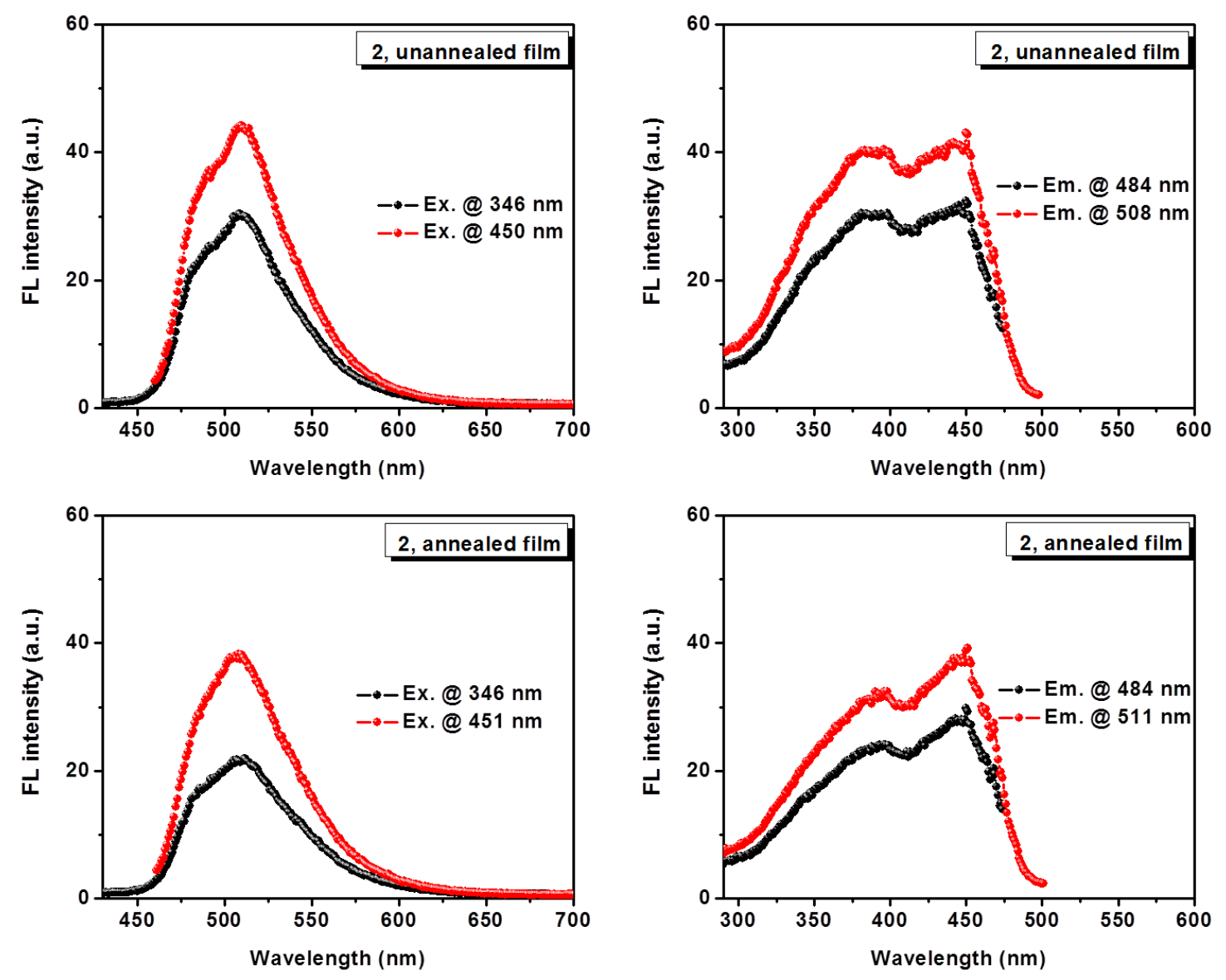

Figure S12. Fluorescence emission and excitation spectra of unannealed and annealed thin films of compound 2 monitored at different wavelengths. 

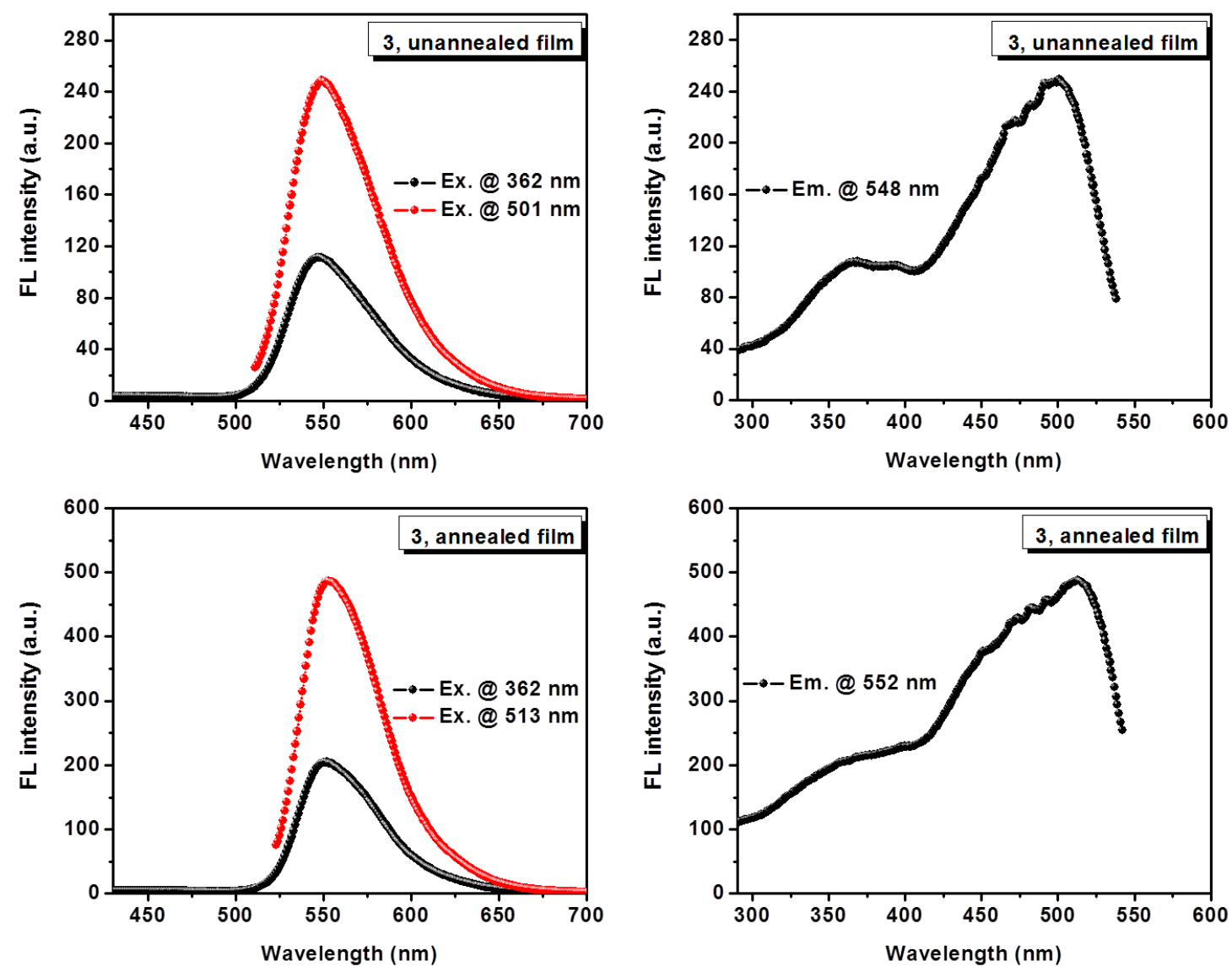

Figure S13. Fluorescence emission and excitation spectra of unannealed and annealed thin films of compound 3 monitored at different wavelengths. 

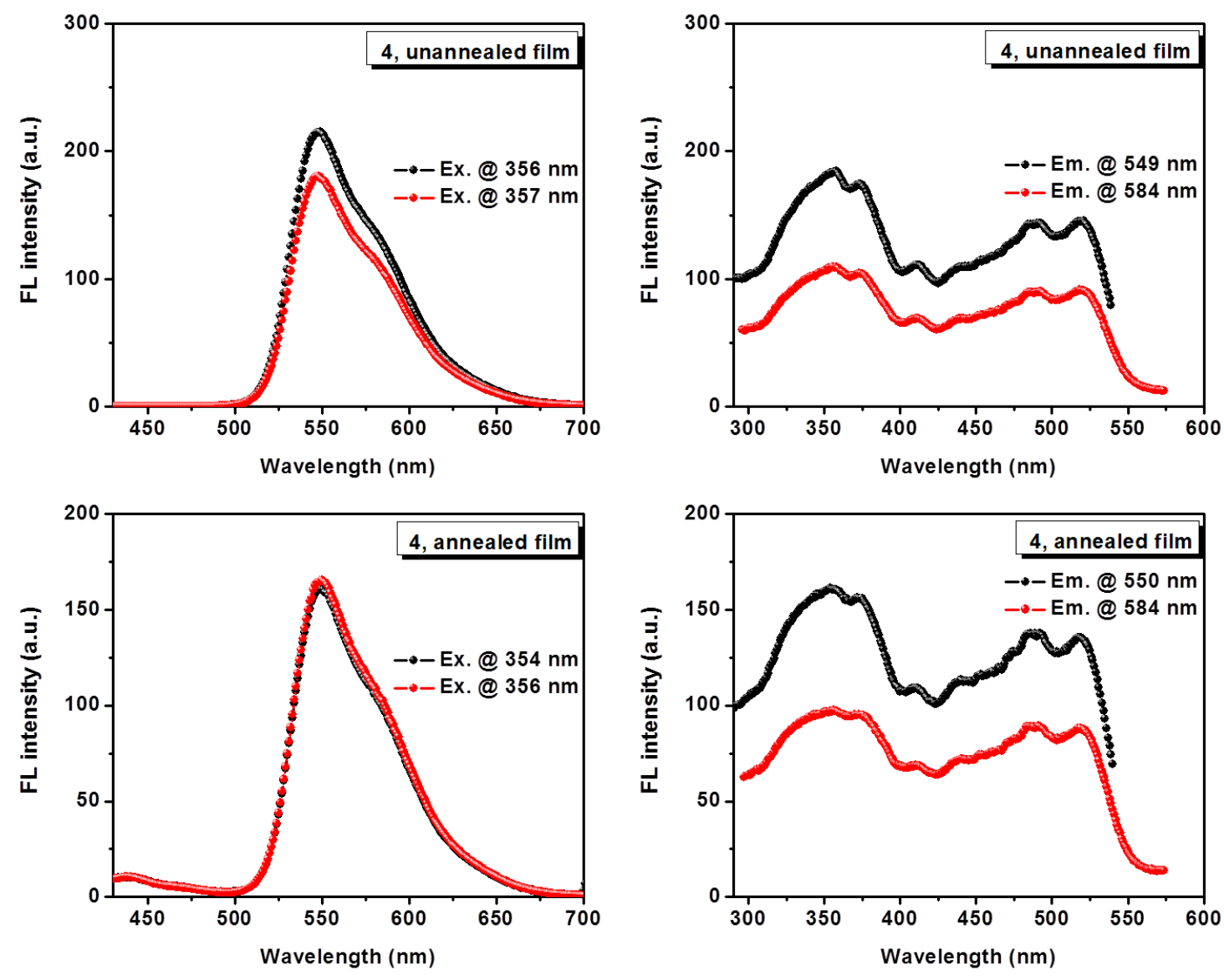

Figure S14. Fluorescence emission and excitation spectra of unannealed and annealed thin films of compound 4 monitored at different wavelengths.

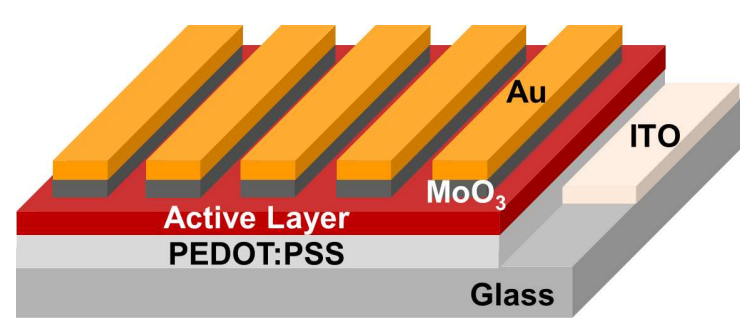

Figure S15. The architecture of the hole-only devices. 
(a)
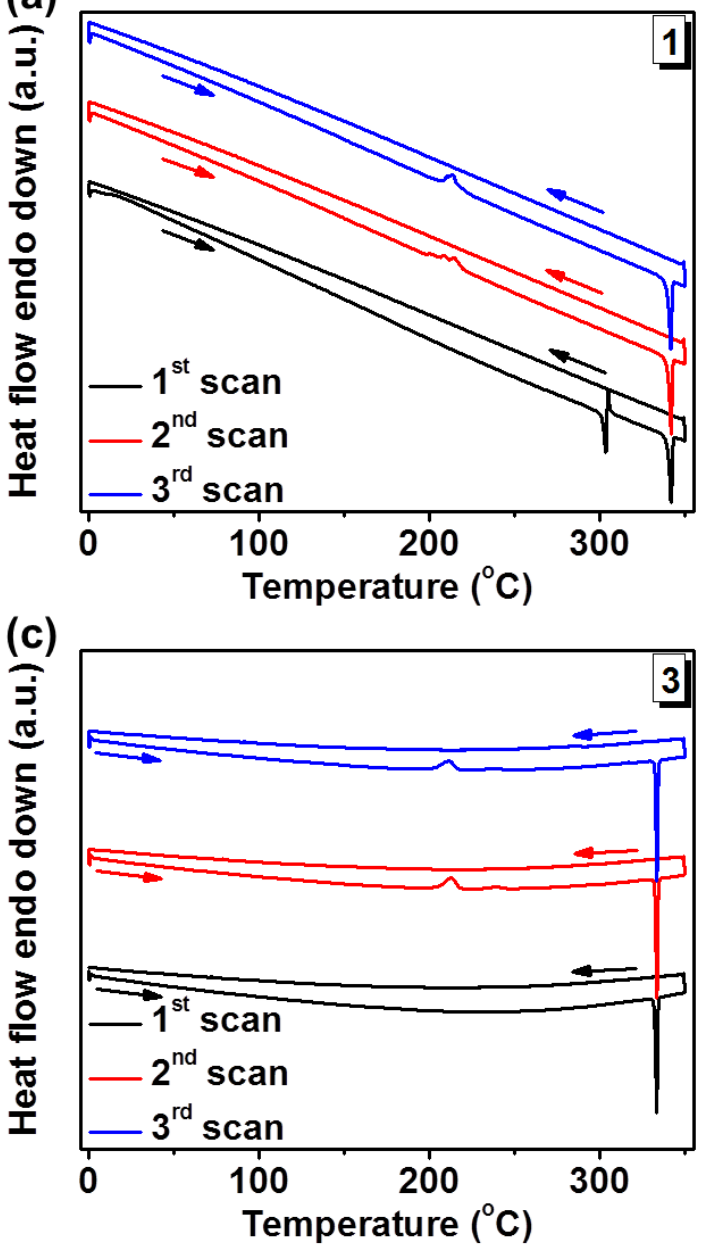

(b)

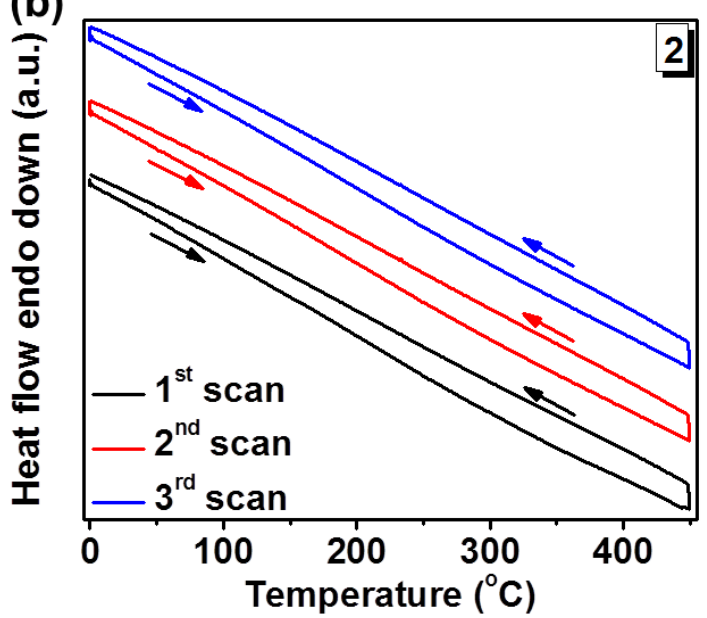

(d)

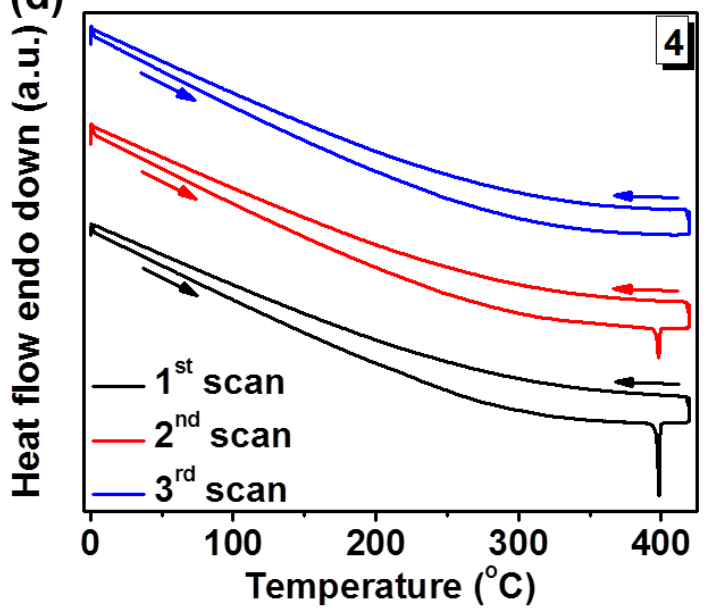

Figure S16. $(a-d)$ DSC thermograms of compounds 1-4 with a heating and cooling rate of $10{ }^{\circ} \mathrm{C} / \mathrm{min}$. 


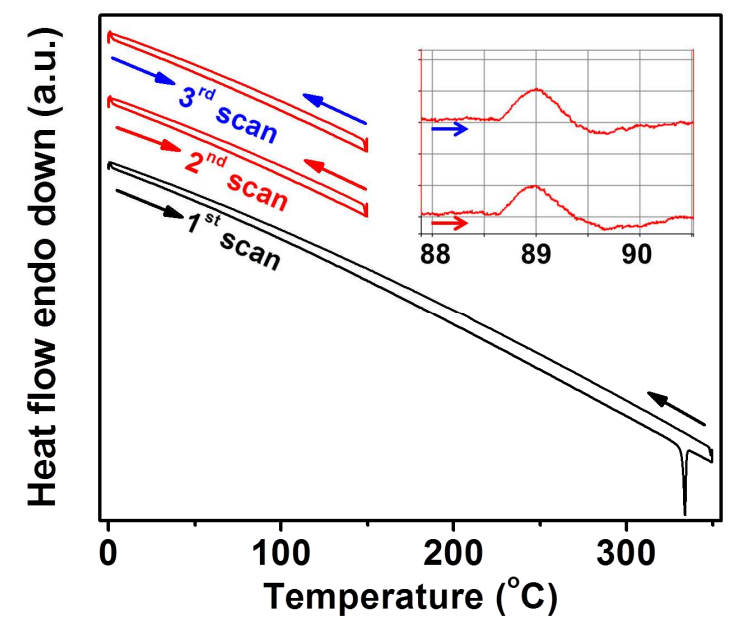

Figure S17. DSC thermograms of compound 3 with a heating and cooling rate of $10{ }^{\circ} \mathrm{C} / \mathrm{min}$. The inset shows zoomed areas of corresponding thermograms. 

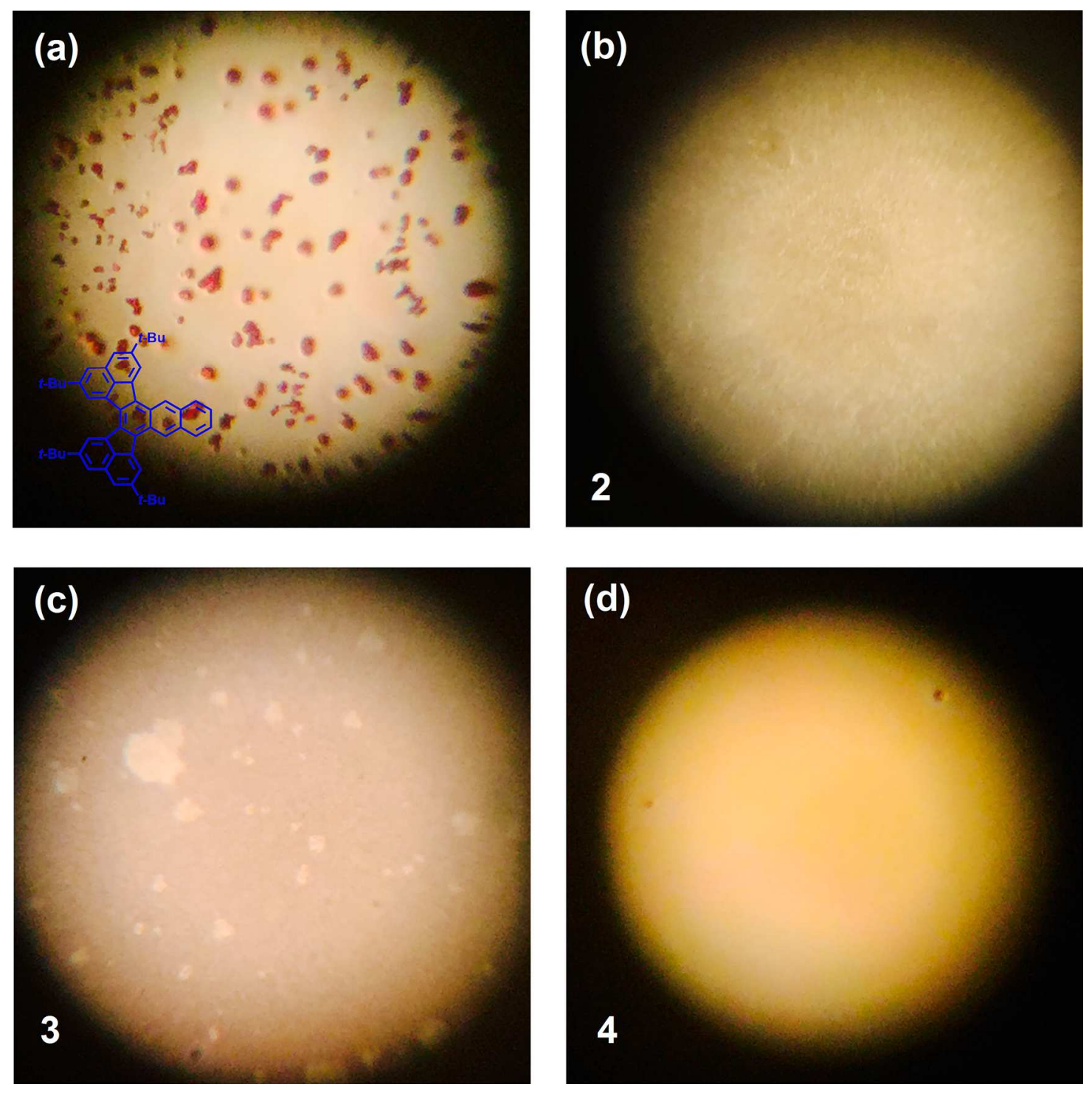

Figure S18. Comparison of optical microscopy images of spin-coated compounds: (a) 2,5,8,17tetra-tert-butylacenaphtho[1,2-j]naphtho[2,3-l]fluoranthene, (b-d) 2-4 (thermally annealed). The diameter of the circular scope is $5 \mathrm{~mm}$. The thin films of $\mathbf{2}$ and $\mathbf{4}$ are amorphous, whereras the thin film of $\mathbf{3}$ contains embedded shiny crystalline domains of different sizes ranging from tens to hundreds of microns.

Synthesis of 2,5,8,17-Tetra-tert-butylacenaphtho[1,2-j]naphtho[2,3-l]fluoranthene: 


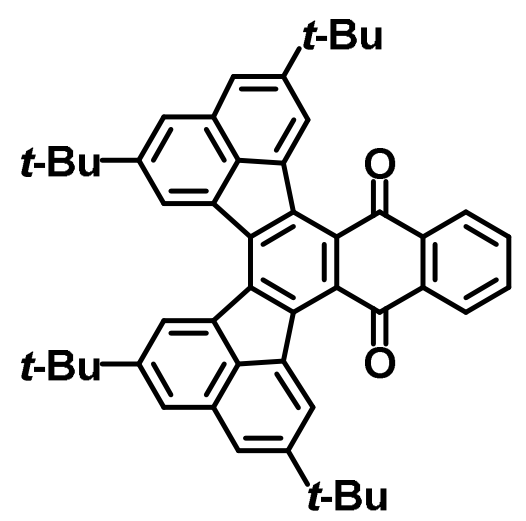

2,5,8,17-Tetra-tert-butylacenaphtho[1,2-j]naphtho[2,3-l]fluoranthene-10,15-dione.

Thiophene DAT (2.10 g, $3.77 \mathrm{mmol})$ and 1,4-naphthoquinone (600 mg, $3.8 \mathrm{mmol})$ were heated to reflux in nitrobenzene $(8 \mathrm{~mL})$ for $22 \mathrm{~h}$. At which point, another portion of 1,4-naphthoquinone (320 mg, $2.0 \mathrm{mmol}$ ) was added, and reflux was continued for an additional $29 \mathrm{~h}$. The reaction contents were diluted with acetone $(20 \mathrm{~mL})$ and vacuum filtered. The filtrate was poured into water $(100 \mathrm{~mL})$ and steam distilled to remove nitrobenzene. The aqueous contents were extracted with $\mathrm{CH}_{2} \mathrm{Cl}_{2}$. The organic extract was dried over $\mathrm{Na}_{2} \mathrm{SO}_{4}$ and filtered. The solvent was removed under reduced pressure. The extracted residue was combined with the filtered solid and subjected to column chromatography (silica gel; eluent: hexanes, followed by $20 \%$ and then $35 \% \mathrm{CH}_{2} \mathrm{Cl}_{2}-$ hexanes). A yellowish band was collected $\mathrm{R}_{f} 0.51$ TLC (silica gel; eluent: $30 \%$ hexanes-toluene). The eluent was removed under reduced pressure, and the residue triturated with acetonemethanol to give 2,5,8,17-tetra-tert-butylacenaphtho[1,2-j]naphtho[2,3-l]fluoranthene-10,15dione as an orange solid, which was used in the next step without any further purification (520 mg, $0.76 \mathrm{mmol}, 20 \%): \operatorname{mp~} 365^{\circ} \mathrm{C} \mathrm{dec} ;{ }^{1} \mathrm{H}$ NMR (400 MHz, $\left.\mathrm{CDCl}_{3}\right) \delta 1.62(\mathrm{~s}, 18 \mathrm{H}), 1.65(\mathrm{~s}, 18$ H), 7.83-7.86 and 8.43-8.45 (AA'BB' system, $4 \mathrm{H}), 8.01(\mathrm{~d}, J=1.5 \mathrm{~Hz}, 2 \mathrm{H}), 8.05$ (d, $J=1.0 \mathrm{~Hz}$, $2 \mathrm{H}), 9.03(\mathrm{~d}, J=1.0 \mathrm{~Hz}, 2 \mathrm{H}), 9.45(\mathrm{~d}, J=1.0 \mathrm{~Hz}, 2 \mathrm{H}) ;{ }^{13} \mathrm{C} \mathrm{NMR}\left(100 \mathrm{MHz}, \mathrm{CDCl}_{3}\right) \delta 31.8$, $32.0,35.8,35.9,123.1,124.0,124.2,126.8,127.4,129.4,131.0,131.9,133.5,134.5,134.6$, $134.8,140.6,141.2,150.4,151.8,185.9$ (21 of 21 expected resonances observed). 


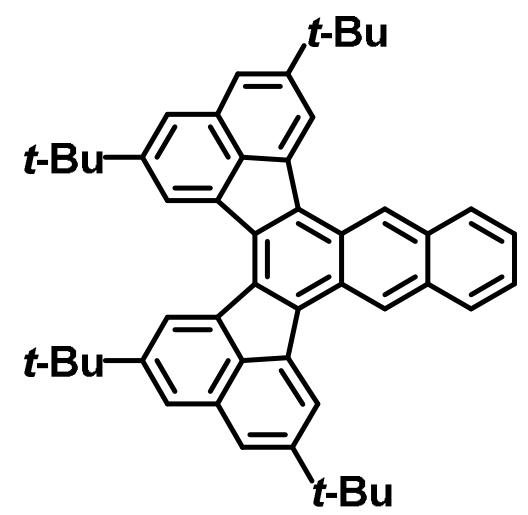

$2,5,8,17$-Tetra-tert-butylacenaphtho[ $[1,2-j]$ naphtho[ $[2,3-l]$ fluoranthene was synthesized by a procedure adapted from the work of Clar et al. ${ }^{\mathrm{S} 1}$ 2,5,8,17-Tetra-tert-butylacenaphtho[1,2$j$ ]naphtho[2,3-l] fluoranthene-10,15-dione (199.9 mg, $0.29 \mathrm{mmol})$, zinc $(1.0 \mathrm{~g})$, and pyridine (10 $\mathrm{mL}$ ) were placed into a two-neck flask and brought to reflux under a closed atmosphere. At reflux, acetic acid $(0.7 \mathrm{~mL}$ ) was added every $30 \mathrm{~min}$ via syringe over the course of $2 \mathrm{~h}$ (total 2.8 $\mathrm{mL})$, and the reaction contents were continued at reflux for $2 \mathrm{~h}$. Water was added $(80 \mathrm{~mL})$ and the contents were heated until the opaque mixture became clear. The resulting precipitate was collected via vacuum filtration. The solid was placed into an amber screw-capped vial and refluxed with nitrobenzene $(1 \mathrm{~mL})$ for $15 \mathrm{~h}$. The reaction contents were poured into methanol (25 $\mathrm{mL}$ ) and filtered. An orange fluorescent band was collected $\mathrm{R}_{f}=0.5 \mathrm{TLC}$ (silica gel; eluent: $20 \%$ toluene-hexanes). Recrystallization from $\mathrm{CHCl}_{3}-\mathrm{MeOH}$ gave 2,5,8,17-tetra-tertbutylacenaphtho[1,2-j]naphtho[2,3-l]fluoranthene as a red solid (118 mg, $0.18 \mathrm{mmol}, 62 \%)$ : $\mathrm{mp}$ $355{ }^{\circ} \mathrm{C} \mathrm{dec} ;{ }^{1} \mathrm{H}$ NMR $\left(400 \mathrm{MHz}, \mathrm{CDCl}_{3}\right) \delta 1.68(\mathrm{~s}, 18 \mathrm{H}), 1.69$ (s, $\left.18 \mathrm{H}\right), 7.52-7.54$ and 8.148.17 (AA'BB' system, 4 H), 7.94 (dd, $J=3.5,1.0 \mathrm{~Hz}, 4 \mathrm{H}), 8.87$ (d, $J=1.0 \mathrm{~Hz}, 2 \mathrm{H}), 8.98$ (d, $J=$ $1.0 \mathrm{~Hz}, 2 \mathrm{H}), 9.50$ (s, $2 \mathrm{H}) ;{ }^{13} \mathrm{C} \mathrm{NMR}\left(100 \mathrm{MHz}, \mathrm{CDCl}_{3}\right) \delta 31.9,35.7,35.8,122.6,122.7,122.9$, $123.6,123.9,125.8,128.6,128.8,129.4,131.8,134.9,135.6,137.0,137.6,150.9,151.3$ (19 of 21 expected resonances observed; but the $\delta 31.9$ resonance may contain two lines). 


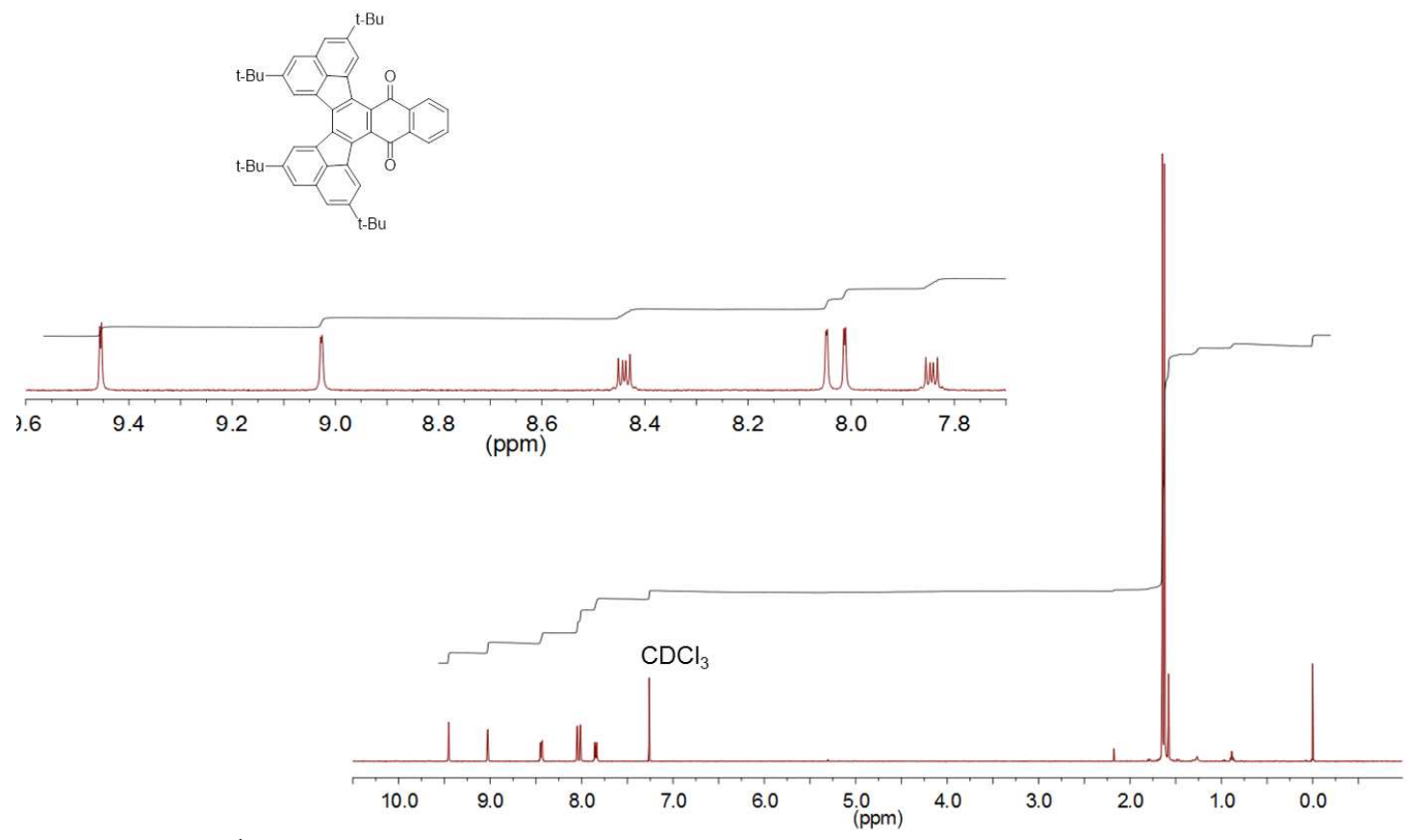

Figure S19. ${ }^{1} \mathrm{H}$ NMR spectrum $\left(400 \mathrm{MHz}^{\mathrm{CDCl}} 3\right)$ of 2,5,8,17-tetra-tert-butylacenaphtho[1,2$j]$ naphtho[2,3-l]fluoranthene-10,15-dione.

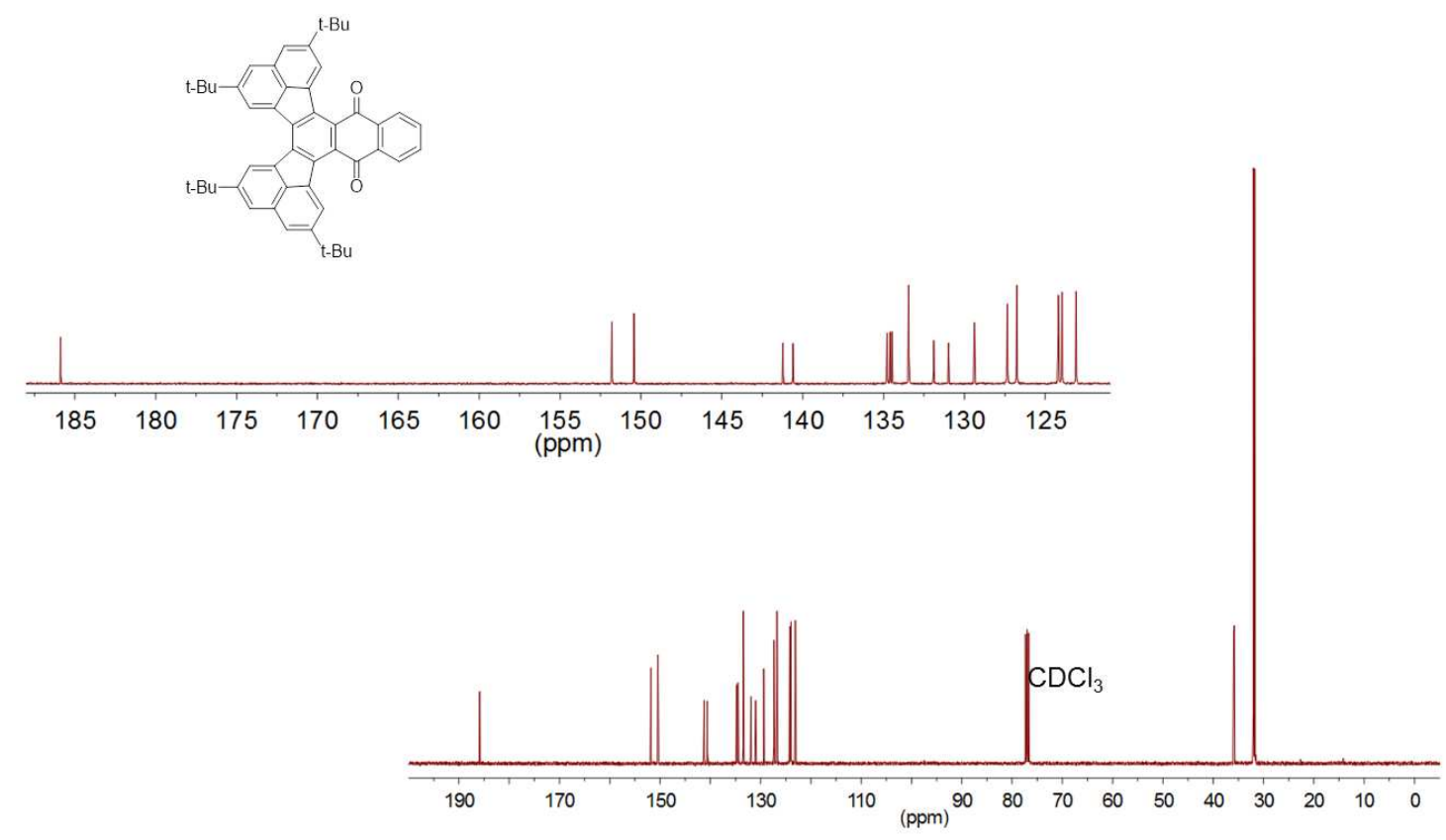


Figure S20. ${ }^{13} \mathrm{C}$ NMR spectrum $\left(100 \mathrm{MHz}, \mathrm{CDCl}_{3}\right)$ of 2,5,8,17-Tetra-tert-butylacenaphtho[1,2$j]$ naphtho[2,3-l]fluoranthene-10,15-dione.
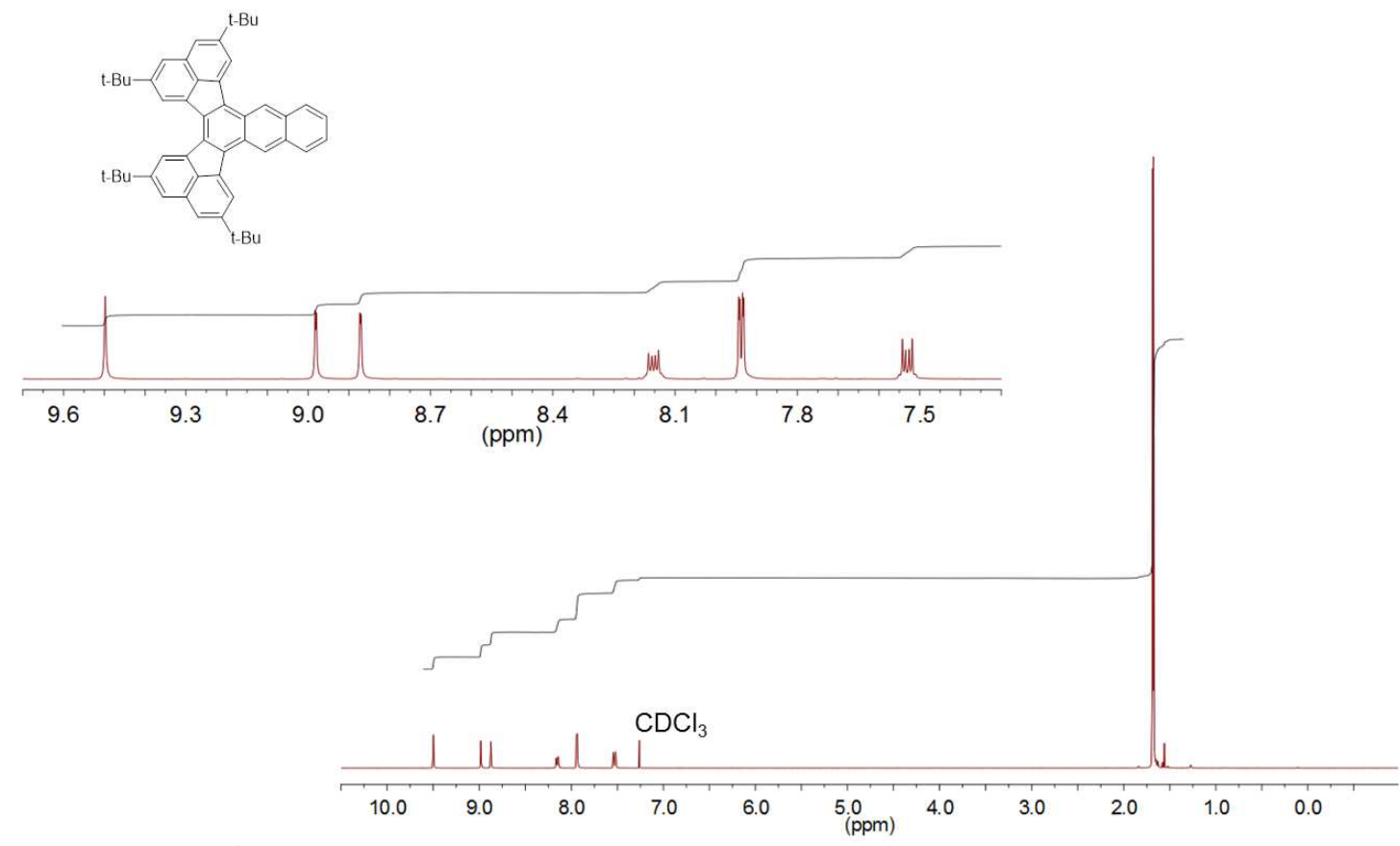

Figure S21. ${ }^{1} \mathrm{H}$ NMR spectrum $\left(400 \mathrm{MHz}, \mathrm{CDCl}_{3}\right)$ of 2,5,8,17-tetra-tert-butylacenaphtho[1,2$j]$ naphtho[2,3-l]fluoranthene. 


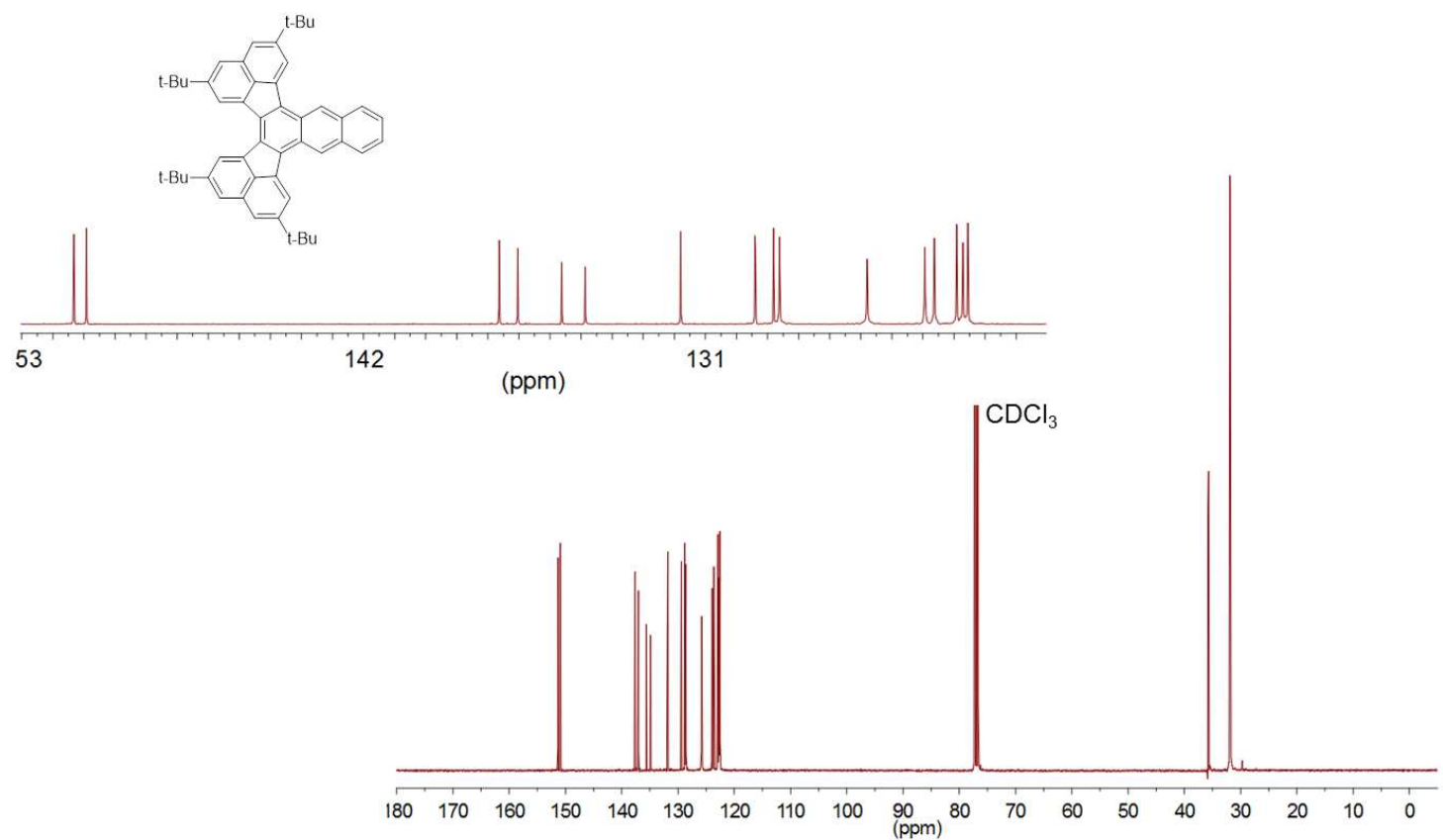

Figure S22. ${ }^{13} \mathrm{C}$ NMR spectrum $\left(100 \mathrm{MHz}, \mathrm{CDCl}_{3}\right)$ of 2,5,8,17-tetra-tert-butylacenaphtho[1,2$j]$ naphtho[2,3-l]fluoranthene.

References:

(S1) Clar, E.; Stephen, J. F. Annellation Effects in the Fluoranthene Series. Tetrahedron 1964, $20,1559-1566$. 